\title{
KOORDINASI ANTAR LEMBAGA PEMERINTAH DALAM PELAYANAN E-KTP DI KECAMATAN RAPPOCINI KOTA MAKASSAR

\author{
Nurhidayat $\mathbf{M}^{\mathbf{1}}$, St. Nurmaeta ${ }^{\mathbf{1}}$, Rudi Hardi ${ }^{1}$ \\ Program Studi Ilmu Pemerintahan Fakultas Ilmu Sosial Dan Ilmu Politik \\ Universitas Muhammadiyah Makassar \\ Jl. Sultan Alaudin No. 259 Makassar 90221 \\ Tlp. 0411-866972 ext. 107. Fax. 0411-865588
}

\begin{abstract}
This study aimed at knowing the Coordination of Inter-government institutions in Electronic ID-card Services as well as at knowing the supporting and obstacles factors of the Coordination of Inter-government institutions in the Electronic ID-card Services in Rappocini district of Makassar. This research was a descriptive - qualitative, the population in this research are also as sample of 31 people. Data were collected by observation, questionnaires and interviews developed by the respondent. The data were analyzed descriptive qualitatively in which analyzing all data collected by the authors, then presented in the form of frequency tabulation completed by respondents' idea obtained from the informants, interviews, and questionnaires. The results showed the Coordination of Inter-Government institutions in Electronic ID-card service in the Rappocini district of Makassar categorized as less effective and influenced by several supporting and inhibiting factors. The inhibiting factor in Electronic ID-card services, namely : (a). Lack of computer facilities and infrastructure devices in regard to the number of mandatory for Electronic ID-card. (b). communities took low active role to queue for electronic ID-card service. (c). Less proposionality of the operator of Electronic ID-card in carrying on its duties and responsibilities. While the supporting factors in Electronic ID-card services, namely: (a). The presence of regulations on population policies in the service of Electronic ID-card, (b). The presence of a proportional local budget from the central government to distribute in any subdistricts in Makassar.
\end{abstract}

Keywords: e-KTP services, inter-agency

\begin{abstract}
ABSTRAK
Penelitian ini bertujuan Untuk mengetahui Koordinasi Antar Lembaga Pemerintahan Dalam Pelayanan EKTP serta untuk mengetahui faktor-faktor yang menjadi pendukung dan penghambat Koordinasi Antar Lembaga Pemerintah Dalam Pelayanan E-KTP di Kecamatan Rappocini Kota Makassar. Penelitian ini adalah Deskriptif-Kualitatif, Populasi dalam penelitian sekaligus merupakan sampel sebanyak 31 orang. Data dikumpulkan dengan menggunakan teknik berupa observasi, kuesioner serta dikembangkan dengan wawancara kepada responden. Data tersebut dianalisis secara Deskriptip kualitatif yaitu menganalisis semua data yang berhasil dikumpulkan penulis, dan selanjutnya disajikan dalam bentuk tabulasi frekuensi dilengkapi dengan tanggapan responden yang diperoleh dari hasil Informan, wawancara, dan kuesioner. Hasil penelitian menunjukkan Koordinasi Antar Lembaga Pemerintah dalam pelayanan e-KTP di Kecamatan Rappocini Kota Makassar dikategorikan kurang efektif dan dipengaruhi oleh beberapa faktor pendukung dan penghambat. Adapun Faktor penghambat dalam Pelayanan e-KTP yaitu : (a).Kurangnya sarana dan prasaranan perangkat komputer di banding jumlah wajib e-KTP. (b).Rendahnya peran aktif masyarakat ikut antrian dalam pelayanan e-KTP. (c).Kurang proposionalnya operator e-KTP dalam melaksanakan tugas dan tanggung jawab. Sedangkan yang menjadi faktor pendukung dalam pelayanan e-KTP yaitu : (a).Adanya regulasi tentang kebijakan kependudukan dalam pelayanan e-KTP, (b). Adanya anggaran APBD yang proposional dari pemerintah pusat untuk distribusikan setiap Kecamatan yang ada di Kota Makassar.
\end{abstract}

Kata kunci: pelayanan e-KTP, antar lembaga. 


\section{A. LATAR BELAKANG}

Saat ini, teknologi memiliki pengaruh besar dalam berbagai bidang kehidupan masyarakat. Salah satunya adalah sistem birokrasi dan layanan publik. Perkembangan teknologi melahirkan konsep e-government, sebuah praktik pemerintahan yang memanfaatkan perkembangan teknologi informasi dan komunikasi untuk meningkatkan kualitas layanan publik dan manajemen pemerintahan.

Pengembangan aplikasi e-government memerlukan pendanaan yang cukup besar sehingga diperlukan kesiapan, baik sisi sumber daya aparat pemerintahan maupun kesiapan dari masyarakat. E-Government dapatlah digolongkan dalam empat tingkatan. Tingkat pertama adalah pemerintah mempublikasikan informasi melalui website. Tingkat kedua adalah interaksi antara masyarakat dan kantor pemerintahan melaui e-mail. Tingkat ketiga adalah masyarakat pengguna dapat melakukan transaksi dengan kantor pemerintahan secara timbal balik. Level terakhir adalah integrasi di seluruh kantor pemerintahan, dimana masyarakat dapat melakukan transaksi dengan seluruh kantor pemerintahan yang telah mempunyai pemakaian database bersama.

Transformasi traditional government menjadi electronic government (E-Government) menjadi salah satu isu kebijakan publik yang hangat dibicarakan saat ini. Di Indonesia $E$ Government baru dimulai dengan inisiatif yang direncanakan beberapa tahun lalu. Tulisan ini mencoba membahas proses pengelolaan pengaduan pelayanan publik berbasis $E$ Government sehingga terciptanya efektivitas pengelolaan pelayanan publik berbasis EGovernment. Berdasarkan definisi dari World Bank, E-Government adalah penggunaan teknologi informasi oleh pemerintah (seperti: Wide Area Network, Internet Dan Mobile Computing) yang memungkinkan pemerintah untuk mentransformasikan hubungan dengan masyarakat, dunia bisnis dan pihak yang berkepentingan. Dalam prakteknya, E-Government adalah penggunaan Internet untuk melaksanakan urusan pemerintah dan penyediaan pelayanan publik yang lebih baik dan cara yang berorientasi pada pelayanan masyarakat.
Secara ringkas tujuan yang ingin dicapai dengan implementasi pengaduan berbasis $E$ Government adalah untuk menciptakan Customer Online dan bukan in-line. E-Government bertujuan memberikan pelayanan tanpa adanya intervensi pegawai institusi publik dan sistem antrian yang panjang hanya untuk mendapatkan suatu pelayanan yang sederhana. Selain itu E-Government juga bertujuan untuk mendukung Good Governance. Penggunaan teknologi yang mempermudah masyarakat untuk mengakses informasi dapat mengurangi korupsi dengan cara meningkatkan transparansi dan akuntabilitas lembaga publik. E-Government dapat memperluas partisipasi publik dimana masyarakat dimungkinkan untuk terlibat aktif dalam pengambilan keputusan/kebijakan oleh pemerintah. E-Government juga diharapkan dapat memperbaiki produktifitas dan efisiensi birokrasi serta meningkatkan pertumbuhan ekonomi. Adapun konsep dari E-Government adalah menciptakan interaksi yang ramah, nyaman, transparan, dan murah antara pemerintah dan masyarakat (G2C-Government to Citizens) pemerintah dan perusahaan bisnis (G2B-Government to Business Enterprises) dan hubungan antar pemerintah (G2G-InterAgency Relationship).

E-Government dengan menyediakan pengaduan pelayanan baik melalui internet maupun melalui alat eletronik pemerintahan yang lain (sms, telepon) dapat dibagi dalam beberapa tingkatan yaitu penyediaan pengaduan, penyedian informasi, interaksi satu arah, interaksi dua arah, dan transaksi yang berarti pelayanan elektronik secara penuh. Interaksi satu arah bisa berupa fasilitas menDownload informasi yang dibutuhkan. Penangan pengaduan secara Online merupakan contoh interaksi dua arah. Sedangkan pelayanan Elektronik penuh berupa pengambilan keputusan dan Delivery (pembayaran). Berdasarkan fakta yang ada pelaksanaan $E$ Government di Indonesia sebagian besar barulah pada tahap publikasi situs oleh pemerintah baru atau pada tahap pemberian informasi. Akan tetapi perlu digaris bawahi bahwa E-Government bukan hanya sekedar publikasi situs oleh pemerintah. Pemberian 
pelayanan sampai dengan tahap Full-Electronic Delivery Service perlu diupayakan.

Mencermati uraian di atas dan memperhatikan kondisi yang ada, pengelolaan pengaduan pelayanan publik berbasis $E$ Government di Kota Makassar Propinsi Sulawesi Selatan menghadapi beberapa tantangan khususnya yang dihadapi oleh organisasi pemerintah. Salah satu diantaranya adalah masalah sumber daya manusia yang belum memadai. Penerapan E-Government di kantor-kantor publik perlu didukung oleh pegawai yang mengerti mengenai teknologi. Yang juga diperlukan adalah pegawai yang mau belajar dan mampu menanggapi perubahan (Manage Change). Teknologi informasi berubah secara cepat sehingga kemauan belajar pun dituntut untuk dimiliki setiap pegawai lembaga publik. Selain itu pengelolaan pengaduan pelayanan publik berbasis $E$ Government memerlukan perubahan dalam organisasi dan dukungan ketrampilan baru. Organisasi pemerintahan di Indonesia perlu ditata ulang untuk dapat pengelolaan pengaduan pelayanan publik berbasis E-Government secara efektif. KKN yang membudaya mempengaruhi kesiapan dalam mempermudah akses publik melalui informasi dalam melakukan pengaduan terhadap pelayan publik. Jika KKN tidak dituntaskan terlebih dahulu akan ada oknum yang akan mempergunakan kesempatan dengan mempersulit mendapatkan informasi dan proses pengaduan. Budaya korupsi perlu dihilangkan dalam rangka meningkatkan pelayanan sehingga kemudahan yang dicapai dalam pengaduan berbasis E-Government dapat disediakan dengan tidak menimbulkan ongkos ekonomi yang lebih tinggi yang harus dibayar masyarakat. Perlunya diciptakan budaya yang menomorsatukan masyarakat dan budaya melayani. Infrastruktur yang belum memadai termasuk kurangnya tempat akses umum merupakan tantangan yang lain. Penyediaan pelayanan pangaduan melalui E-Government perlu didukung oleh tingkat penetrasi internet yang tinggi baik dari rumah tangga ataupun stand/kios umum. Sebagai gambaran pada tahun 2001 penetrasi internet baru mencapai 1,9 juta penduduk atau 7,6 persen dari total populasi Indonesia. Pada tahun 2002 dengan 667.000 jumlah pelanggan internet dan 4.500.000 pengguna komputer dan telepon, persentasi penggunaan internet di Indonesia sangatlah rendah. Tingkat penetrasi yang rendah ini juga merupakan suatu kendala. (Sumber:Asosiasi Penyelenggara Jasa Internet Indonesia/APJII).

Pemerintah kota Makassar terus melakukan terobosan dan inovatif. Terbosan yang kini tengah dilakukan Pemerintah Kota Makassar adalah menambahkan sidik jari dalam Kartu Identitas Penduduk (KTP). Terobosan ini sebagai tambahan identitas seseorang di samping Nomor Induk Kependudukan (NIK) Nasional. Pemerintah Kota Makassar berpendapat perlu menambahkan satu ciri untuk membedakan satu orang dengan yang lain. Tujuannya untuk memproteksi terhadap Identitas Penduduk, menghindari pemalsuan identitas penduduk, menghindari pemalsuan identitas kependudukan agar tidak terjadi identitas ganda. Ada tertib administrasi kependudukan juga memungkinkan Pemerintah Kota Makassar mengembangkan layanan public berbasis TI.

Sejauh ini, layanan pembuatan E-KTP tersebut dapat diselesaikan dalam sehari. Syaratnya cukup dengan surat pengantar dari RT dan RW serta biaya administrasi sebanyak Rp 10.000. Adapun layanan sidik jari syaratnya berupa fotocopy KTP serta KK. Untuk itu, sejak awal tahun 2008 Pemerintah Kota menggelar kegiatan memindai sidik jari bagi warganya berusia 11 tahun ke atas yang berjumlah kurang lebih 3 juta jiwa. Hingga akhir November 2008 ini, telah terlaksana sekitar 75\%. Cara pengumpulan sidik jari dilakukan dengan jemput bola ke setiap RW. Agar sidik jari terkumpul dengan cepat, Pemerintah Kota Makassar membuat inovasi dengan menyelenggarakan KTP online, khususnya layanan perpanjangan KTP dan sidik jari.

Pemerintah Kota sudah menyiapkan konsep pengembangan sistem intergrasi dalam pemanfaatan E-KTP di samping sebagai identitas diri dapat juga dimanfaatkan sebagai integrasi untuk intervensi program pemerintah dan penggali potensi. Nantinya semua transaksi pelayanan masyarakat, intervensi 
program dan perizinan akan terintegrasi dengan databes kependudukan (NIK) melalui KTP yang telah terintegrasi tersebut akan dapat terdeteksi identitas penerima bantuan bagi keluarga miskin. Pada sektor pendidikan, dapat dimanfaatkan juga sebagai validasi pembayaran biaya sekolah dan penerima bantuan beasiswa.

KTP merupakan identitas resmi penduduk sebagai bukti diri yang diterbitkan oleh Instansi Pelaksana yang berlaku di seluruh Wilayah Negara Kesatuan Republik Indonesia. Kartu ini wajib dimiliki bagi Warga Negara Indonesia (WNI) dan Warga Negara Asing (WNA) yang memiliki Izin Tinggal Tetap (ITAP) yang sudah berumur 17 tahun atau sudah pernah kawin atau telah kawin. KTP bagi WNI berlaku selama lima tahun dan tanggal berakhirnya disesuaikan dengan tanggal dan bulan kelahiran yang bersangkutan. KTP bagi WNA berlaku sesuai dengan masa Izin Tinggal Tetap. Khusus warga yang telah berusia 60 tahun ke atas, mendapat KTP seumur hidup yang tidak perlu diperpanjang setiap lima tahun sekali.

Koordinasi pokok Dinas dan Kecamatan (khusus menyangkut pelayanan) database kependudukan. Maksudnya yaitu : Setiap penyajian data harus melalui Database kependudukan, Kondisi menyangkut blangko dan formulir, Kondisi pada masalah pembayaran (jaringan kesalahan) dan Koordinasi Adminstrasi pendukung pelayanan penerbitan angka kependudukan.

Penulis tertarik meneliti terhadap persoalan di atas dengan harapan hasil penelitian dapat memberikan hasil dan berguna bagi Kota Makassar.

\section{B. KERANGKA TEORITIS}

Koordinasi adalah usaha penyesuaian bagian-bagian yang berbeda, agar kegiatan dari pada bagian-bagian itu selesai pada waktunya, sehingga masing-masing dapat memberikan sumbangan usahanya secara maksimal, agar memperoleh hasil secara keseluruhan. Koordinasi terhadap sejumlah bagian-bagian yang besar pada setiap usaha yang luas dari pada organisasi demikian pentingnya sehingga beberapa kalangan menempatkannya di dalam pusat analisis. Koordinasi yang efektif adalah suatu keharusan untuk mencapai administrasi/manajemen yang baik dan merupakan tanggung jawab yang langsung dari pimpinan. Koordinasi dan kepemimpinan tidak bisa dipisahkan satu sama lain oleh karena itu satu sama lain saling mempengaruhi. Kepemimpinan yang efektif akan menjamin koordinasi yang baik sebab pemimpin berperan sebagai koordinator. Menurut Jame D. Mooney, mendefinisikan koordinasi yaitu sebagai pencapaian usaha kelompok secara teratur dan kesatuan tindakan di dalam mencapai tujuan bersama.

Setelah mempelajari arti, definisi, dan ciriciri koordinasi, maka pada hakikatnya koordinasi dapat dijelaskan sebagai berikut: (Handayaningrat,1982): Koordinasi adalah akibat logis dari pada adanya prinsip pembagian habis tugas di mana setiap satuan kerja (unit), hanyalah melaksanakan sebagian tugas pokok organisasi secara keseluruhan, Koordinasi timbul karena adanya prinsip fungsional di mana setiap satuan kerja (unit), hanyalah melaksanakan sebagian fungsi dalam suatu organisasi, Koordinasi juga akibat adanya rentang/jenjang pengadilan (span of control), di mana pimpinan wajib membina, membimbing, mengarahkan, dan mengendalikan berbagai kegiatan/usaha yang dilakukan oleh sejumlah bawahan di bawah wewenang dan tanggung jawabnya, Koordinasi sangat diperlukan dalam suatu organisasi yang besar dan komplek, di mana berbagai fungsi dan kegiatan harus dilakukan oleh berbagai satuan kerja (unit) yang harus dilakukan secara terpadu dan simultan (sinkron), Koordinasi juga sangat diperlukan dalam suatu organisasi yang dibentuk berdasarkan atas prinsip jalur ini dan staf, karena kelemahan yang pokok dalam bentuk organisasi ini ialah masalah koordinasi, Koordinasi hanya dapat berhasil dengan bantuan sarana komunikasi yang baik. Oleh karena itu komunikasi administrasi yang disebut hubungan kerja memegang perana yang sangat penting tercapaianya koordinasi. Sebagaimana telah disebutkan di atas bahwa Koordinasi adalah hasil akhir dari pada hubungan kerja (Komunikasi) dan Pada 
hakikatnya koordinasi adalah perwujudan dari pada kerja sama, saling membantu dan menghargai/menghayati tugas dan fungsi serta tanggung jawab masing-masing. Hal ini disebabkan karena setiap satuan kerja (unit) dalam melaksanakan kegiatannya, tergantung atau interdepensi inilah yang mendorong diperlukan adanya kerja sama.

Dalam administrasi Pemerintah, koordinasi dimaksudkan untuk menyerasikan dan menyatukan kegiatan yang dilakukan oleh pejabat pimpinan dan kelompok pejabat pelaksana. Suatu tindakan pelaksanaan yang terkoordinasikan berarti kegiatan kelompok pejabat baik pimpinan dan para pelaksanaan menjadi serasi, seirama dan terpadu dalam pencapaian tujuan bersama. (Handayaningrat, 1982). Berdasarkan atas hubungan antara pejabat yang mengkoordinasikan dengan pejabat yang dikoordinasikan, maka dapat dibedakan 2 (dua) jenis koordinasi, yaitu: Koordinasi Internal dan Koordinasi Eksternal. Koordinasi Internal terdiri atas Koordinasi Vertikal, Koordinasi Horisontal, dan Koordinasi Diagonal dan Koordinasi Eksternal termasuk koordinasi fungsional. Dalam koordinasi Eksternal terdiri atas Horisontal dan Diagonal.

Sekalipun pada umumnya telah disadari pentingnya koordinasi dalam proses administrasi/managemen Pemerintah, tetapi kenyataan dalam praktek tidak jarang terdapat berbagai masalah yang menyebabkan kurang efektif nya pelaksanaan koordinasi yang diperlu-kan, sehingga pencapaian sasaran/ tujuan tidak selalu berjalan sebagaimana yang diharapakan. (Handayaningrat,1982)

Adapun berbagai faktor yang dapat menghambat tercapainya koordinasi itu adalah sebagai berikut: (Handayaningrat, 1982):

a. Hambatan-hambatan dalam koordinasi vertikal (struktural).

Dalam koordinasi vertikal (struktural) sering terjadi hambatan-hambatan, disebabkan perumusan tugas, wewenang dan tanggung jawab tiap-tiap satuan kerja (unit) kurang jelas.

b. Hambatan-hambatan dalam koordinasi fungsional.

Hambatan-hambatan yang timbul pada koordinasi fungsional, baik yang horisontal maupun diagonal, disebabkan karena antara yang mengkoordinasi dengan yang dikoordinasikan tidak terdapat hubungan hirarkhis (garis komando).

Salah satu kewenangan penting dari Kepala Wilayah yaitu kewenangan untuk menjalankan koordinasi atau kegiatan antara Instansi Vertikal dengan Dinas Daerah, baik dalam perencanaan maupun dalam pelaksanaan untuk mencapai daya guna dan hasil guna yang sebesar-besarnya. (Soejito,1981)

Betapa pentingnya arti koordinasi dalam pemerintahan dapatlah dirasakan bila kita perhatikan dalam pengaruh yang berbeda yang didapatkan dalam dinas-dinas umum, dan berapa banyak orang dinas itu terbagi biasanya sering kali adanya kepentingan dalam dinas itu yang nampaknya saling bertentangan. Akan tetapi orang sekaligus dapat mengerti pula bahwa masalah koordinasi itu merupakan salah satu dari problemaproblema pemerintahan yang sangat penting. Tugas koordinasi ini, sejak masa pemerintahan Hindia Belanda dahulu sampai kini selalu diletakkan dipundak Kepala Wilayah yang tidak hanya bertugas untuk mengkoordinasikan antara Instansi Vertikal dan Dinas Daerah.

Dalam mengkoordinasikan kegiatankegiatan Instansi Vertikal , begitu juga antara Instansi Vertikal dengan Pemerintahan Daerah, dan Kepala Daerah harus selalu memperhatikan dan tidak boleh bertindak bertentangan dengan ketentuan peraturan perundangundangan yang berlaku. Berhubungan dengan diberikannya tugas koordinasi kepada Wilayah, maka Instansi Vertikal berada di bawah koordinasi Kepala Wilayah selaku Wakil Pemerintah. Dalam hubungan itu, maka Instansi-instansi Vertikal wajib melaporkan segala rencana dan kegiatan untuk memberikan keterangan yang diminta dan mematuhi petunjuk-petunjuk umum yang diberikan oleh Kepala Wilayah. (Soejito,1981)

Koordinasi Pemerintahan adalah suatu kegiatan penyelenggaraan pemerintahan yang harus ditujukan ke arah tujuan yang hendak di capai yaitu yang telah ditetapkan menjadi garis-garis besar haluan Negara dan garisgaris besr haluan pembangunan baik untuk 
tigkat pusat ataupun untuk tingkat daerah, Guna menuju kepada sasaran dan tujuan itu gerak kegiatan harus ada pengendalian sebagai alat untuk menjamin langsungnya kegiatan. Yang dimaksud pengendalian disini adalah kegiatan untuk menjamin kesesuaian karya dengan rencana, program, perintahperintah, dan ketentuan-ketentuan lainnya yang telah ditetapkan termasuk tindakantindakan korektif terhadap ketidakmampuan atau penyimpangan. Proses pengendalian menghasilkan data-data dan fakta-fakta baru yang terjadi dalam pelaksanaan, ini semua berguna bagi pimpinan perencanaan di pelaksanaan. Apa yang telah direncanakan, diprogramkan tidak selalu cocok dengan kenyataan operasionalnya dalam rangka inilah pengendalian berguna sekali bagi perencanaan selanjutnya. Selama pekerjaan berjalan, pengendalian digunakan sebagai pejaga dan pengamanan. Dalam hal ini pengendalian berguna bagi keperluan koreksi pelaksanaan operasionil, sehingga tujuan haluan tidak menyimpang dari rencana.

Koordinasi dalam pelaksanaan suatu rencana, pada dasarnya merupakan salah satu aspek dari pengendalian yang sangat penting. Koordinasi disini adalah suatu proses rangkaian kegiatan menghubungi, bertujun untuk menyelaraskan tiap langkah dan kegiatan dalam organisasi agar tercapai gerak yang tepat dalam mencapai sasaran dan tujuantujuan yang telah ditetapkan, selain sebagai suatu proses, koordinasi itu dapat juga diartikan sebagai suatu pengatutran yang tertib dari kumpulan/gabungan usaha untuk menciptakan kesatuan tindakan. Maka koordinasi pemerintahan merupakan pengaturan yang aktif, bukan pengaturan yang pasif berupa membuat pengaturan terhadap setiap gerak dan kegiatan hubungan kerja antara beberapa pejabat pemerintah baik pusat maupun daerah serta lembaga-lembaga pemerintahan yang mempuyai tugas kewajiban dan wewenang yang saling berhubungan satu sama lain, dimana pengaturan bertujuan untuk mencegah terjadinya kesimpangsiuran dan saling tumpangtindih kegiatan yang mengakibatkan pemborosan-pemborosan dan pengaruh yang tidak baik terhadap semangat dan tertib kerja.
Pelayanan publik dengan demikian dapat diartikan sebagai pemberian layanan (melayani) keperluan orang atau masyarakat yang mempunyai kepentingan pada organisasi itu sesuai dengan aturan pokok dan tata cara yang telah ditetapkan. (Sinanmbela, 2008). Sebagaimana telah dikemukakan terdahulu bahwa pemerintahan pada hakekatnya adalah pelayanan kepada masyarakat. Karenanya birokrasi publik berkewajiban dan bertanggung jawab untuk memberikan layanan baik dan profesional. Pelayanan publik (Public Services) oleh birokrasi publik tadi adalah merupakan salah satu perwujudan dari fungsi aparatur negara sebagai abdi masyarakat di samping sebagai abdi negara. Pelayanan publik (Public Services) oleh birokrasi publik dimaksudkan untuk mensejahterakan masyarakat (warga negara) dari suatu negara kesejahteraan (Welfare State).

Prinsipnya adalah layanan yang cepat, menyenangkan, tidak mengandung kesalahan, mengikuti proses, dan prosedur yang telah ditetapkan terlebih dahulu. Proses dan prosedur itulah yang harus disusun secara rapi dan teliti, disertai semua perangkat yang dituntut dalam proses itu. Prosedur itu harus terinci, dan harus diikuti, baik oleh yang melayani maupun oleh yang dilayani. Jadi yang berkualitas itu tidak hanya ditentukan oleh pihak yang melayani, tetapi juga yang ingin dipuaskan. Pelaksanaan pelayanan sebagai suatu proses, unsur proses layanan terdiri atas : (1) tugas layanan, (2) prosedur layanan, (3) kegiatan layanan, (4) dan pelaksana layanan. Unsur-unsur tersebut tidak dapat dipisahkan satu sama lain, karena ke empatnya akan membentuk proses kegiatan. (Moenir, 2000:186). Supaya pelayanan umum dapat berfungsi perlu dilandaskan oleh kesadaran akan tugas, tanggung jawab dan timbang rasa yang tinggi, agar tugas layanan dapat terlaksana dengan baik dan memuaskan. Dalam hubungan ini khusus Pegawai Negeri akan kedudukannya dalam Sistem Administrasi Negara Republik Indonesia selaku abdi negara dan abdi masyarakat.

Keberhasilan pelayanan yang diberikan kepada masyarakat sangat tergantung pada pemberian pelayanan tersebut, ini dapat dikaji melalui mutu dan kualitas layanan tersebut, 
mutu dan kualitas layanan biasanya dipengaruhi oleb beberapa faktor, diantaranya:

a. Faktor Kesadaran.

Kesadaran menunjukkan suatu keadaan jiwa seseorang, dengan adanya kesadaran terhadap tugas yang diemban, maka akan membawa seseorang kepada keikhlasan dan kesungguhan dalam menjalankan atau melaksanakan tugas pekerjaannya. Karena itu dengan adanya kesadaran pada pegawai, diharapkan mereka melaksanakan tugas dengan penuh keikhlasan, kesungguhan, dan disiplin.

\section{b. Faktor Aturan}

Aturan adalah perangkat penting dalam segala tindakan dan perbuatan orang. Dalam organisasi kerja aturan dibuat oleh manajemen sebagai pihak yang berwenang mengatur segala sesuatu yang ada di organisasi kerja tersebut.

\section{c. Faktor Organisasi}

Organisasi pelayanan pada dasarnya tidak berbeda dengan organisasi pada umumnya, namun dalam penerapannya memiliki perbedaan sedikit, karena sasaran pelayanan ditujukan secara khusus kepada manusia yang mempunyai watak dan kehendak multi kompleks. Oleh karena itu organisasi yang dimaksud disni tidak semata-mata dalam perwujudan susunan organisasi, melainkan lebih banyak pada pengaturan dan mekanisme kerjanya yang harus mampu menghasilkan pelayanan yang memadai. Karena organisasi adalah mekanisme maka perlu adanya sarana pendukung yang berfungsi memperlancar mekanisme itu. Sarana pendukung itu ialah sistem, prosedur, dan metode.

\section{d. Faktor Pendapatan}

Pendapatan adalah seluruh penerimaan seseorang sebagai imbalan atas tenaga atau pikiran yang telah dicurahkan untuk orang lain atau badan organisasi, baik dalam bentuk uang, maupun fasilitas dalam jangka waktu tertentu. Dalam kaitannya dengan optimilisasi pelayanan yang diberikan oleh petugas layanan, maka sulit diharapkan mereka akan memberikan layanan yang maksimal jika tingkat pendapatannya tidak memenuhi kebutuhan minimalnya. Artinya petugas dapat saja melalaikan tugasnya untuk mencari tambahan penghasilan lain, maka dengan demikian tugas pelayanan akan terabaikan.

e. Faktor Kemampuan dan Keterampilan Kemampuan menunjukkan pada pengertian seseoarang dapat melakukan tugas/pekerjaan sehingga menghasilkan barang atau jasa sesuai dengan yang di harapakan. Sementara keterampilan ialah kemampuan melaksanakan tugas/pekerjaan dengan menggunakan anggota badan dan peralatan kerjayang tersedia. Dengan pengertian tersebut dapat diperjelaskan bahwa keterampilan lebih banyak menggunakan unsur angota badan dari pada unsur lain.

Sasaran yang ingin dicapai dalam pelayanan masyarakat adalah kepuasan masyarakat. Suatu sasaran yang cukup sederhana, mudah diucapkan tetapi tidak mudah untuk mencapainya, mengingat ukuran kepuasan setiap orang berbeda-beda. Namun demikian bukan berarti tidak ada indikator umum yang bisa dipakai untuk mengukur kepuasan masyarakat. Indikator itu adalah masyarakat dapat menerima perlakuan dan hasil layanan dengan kegembiraan dan keikhlasan. Dalam konteks ini kepuasan mempunyai dua komponen besar yaitu: komponen layanan dan komponen modul. Dalam komponen Iayanan, beberapa hal pokok yang harus diperhatikan untuk memberikan kepuasan adalah tingkah laku yang sopan, cara penyampaian sesuatu yang berkaitan dengan apa diterima oleh orang yang bersangkutan, waktu penyampaian yang tepat serta keramah tamahan.

Sistem kependudukan melalui E-KTP atau Kartu Tanda Penduduk Elektronik merupakan cara baru yang akan ditempuh oleh pemerintah untuk memberikan identitas kepada masyarakat. E-KTP memang merupakan cara jitu yang dilakukan pemerintah untuk membangun database kependudukan secara nasional. Dengan menggunakan sistim biometrik yang ada di dalamnya, maka setiap 
pemiliki E-KTP dapat terhubung kedalam satu database nasional, sehingga setiap penduduk hanya memerlukan 1 KTP saja. KTP Elektronik menggunakan sistem biometrik atau sidik jari, sehingga setiap warga hanya membutuhkan satu KTP saja yang dapat dihubungkan dengan database nasional, Pihak BBPT mengatakan bahwa pemerintah akan segera menerapkan teknologi yang siap pakai tersebut, untuk menggantikan sistem kependudukan konvensional yang sudah ada. (Ilham,2012)

Program E-KTP dilatar belakangi oleh sistem pembuatan KTP konvensional di Indonesia yang memungkinkan seseorang dapat memiliki lebih dari satu KTP. Hal ini disebabkan belum adanya basis data terpadu yang menghimpun data penduduk dari seluruh Indonesia. Fakta tersebut memberi peluang penduduk yang ingin berbuat curang terhadap negara dengan menduplikasi KTP-nya.

Autentikasi Kartu Identitas (E-ID) biasanya menggunakan biometrik yaitu verifikasi dan validasi sistem melalui pengenalan karakteristik fisik atau tingkah laku manusia. Ada banyak jenis pengamanan dengan cara ini, antara lain sidik jari (fingerprint), retina mata, DNA, bentuk wajah, dan bentuk gigi. Pada E-KTP yang digunakan adalah sidik jari. Penggunaan sidik jari E-KTP lebih canggih dari yang selama ini telah diterapkan untuk SIM (Surat Izin Mengemudi). Sidik jari tidak sekedar dicetak dalam bentuk gambar seperti di SIM, tetapi juga dapat dikenali melalui chip yang terpasang di kartu. Data yang disimpan di kartu tersebut telah dienkripsi dengan algoritma kriptografi tertentu. (Fradityadi, 2011). Data yang terpatri dalam chip E-KTP tentu merupakan bagian dari data yang ada dalam database. Yang jelas, data yang termuat dalam EKTP harus merupakan bagian dari informasi permanen termasuk kode identitas. Data inilah yang akan dijadikan sebagai kunci untuk mengakses database. E-KTP yang dipalsukan akan ketahuan karena ketika isinya digunakan untuk mengakses database, kuncinya tidak ditemukan dan akses ditolak. (Sudibyo,2011).

Seharusnya penyelenggaraan E-KTP dan E-Government kita yang baru dimulai saat ini, mustinya lebih canggih ketimbang mereka yang sudah lebih dulu menyelenggarakan.
Mereka pada saat itu masih lebih banyak keterbatasan teknologi ketimbang saat ini. Sehingga mungkin E-Government diselenggarakan lebih dulu untuk meningkatkan efisiensi dan efektivitas layanan pemerintah, dan E-KTP menyusul atau bahkan masih dalam proses penyelenggaraan. (Sudibyo,2011).

Pemerintah kota Makassar terus melakukan terobosan dan inovatif. Terbosan yang kini tengah dilakukan Pemerintah kota Makassar adalah menambahkan sidik jari dalam Kartu Identitas Penduduk (KTP). Terobosan ini sebagai tambahan identitas seseorang di samping Nomor Induk Kependudukan (NIK) Nasional. Pemerintah kota Makassar berpendapat perlu menambahkan satu ciri untuk membedakan satu orang dengan yang lain. Tujuannya untuk memproteksi terhadap Identitas Penduduk, menghindari pemalsuan identitas penduduk, menghindari pemalsuan identitas kependudukan agar tidak terjadi identitas ganda. Ada tertib administrasi kependudukan juga memungkinkan Pemerintah kota Makassar mengembangkan layanan public berbasis TI.

\section{METODE PENELITIAN}

Penelitan ini dilaksanakan dikantor Kecamatan Rappocini Kota Makassar, karena belum ada Program E-KTP baru tentang pelajaran yang menyangkut masalah pengadaan EKTP dan memudahkan untuk mendapatkan data pemohon E-KTP yang berasal dari RW, Kelurahan, se-Kecamatan Rappocini Kota Makassar. Tipe penelitian yang di gunakan dalam penelitian ini adalah tipe deskriptif kuantitatif dalam bentuk wawancara kepada petugas yang terkait di Kecamatan, Kelurahan, dan RT/RW sehingga data yang di dapat pada kualitatif tersebut yang akurat (kuantitatif) dan merupakan hasil Koordinasi Antar Lembaga Pemerintah Dalam Pelayanan E-KTP di Kecamatan Rappocini di Kota Makassar. opulasi dalam penelitian ini sebanyak 31 orang yang terdiri dari Pegawai Kecamatan, Pegawai Kelurahan Rappocini Kota Makassar, RW, Pegawai Capil, dan tokoh masyarakat dan Teknik penarikan sampel dalam penelitian ini 
adalah Purposive Sampling yang bertujuan memilih responden secara sengaja, yaitu mereka yang dianggap berkompeten atau dianggap tahu pasti tentang Koordinasi Antar Lembaga Pemerintah Dalam Pelayanan E-KTP, Sampelnya terdiri dari Kepala Dinas Kependudukan Dan Catatan Sipil 1 orang, Kepala Kantor Kecamatan 3 orang, Sekretaris Kecamatan 1 orang, Staf kantor Kecamatan 12 orang, Kelurahan Mappala 3 orang, RW 012 Tidung 1 orang, Tokoh Masyarakat sebanyak 10 orang, jadi jumlah keseluruhan sampel sebanyak : 31 orang yang terdiri dari aparat kecamatan dan tokoh masyarakat. Informan yang penuliasan wawancara : Kepala Dinas Kependudukan Dan Catatan Sipil, Kepala Kantor Kecamatan, Sekretaris Kecamatan, Staf Kantor Kecamatan, Kelurahan Mappala, RW 012 Tidung dan Tokoh Masyarakat. Jenis Data yaitu data kualitatif dan data kuantitatif. Sumber Data yaitu Data dan Data Sekunder. Teknik pengumpulan data dalam penelitian ini adalah: Wawancara, Pengamatan (Observasi). Adapun teknik pengumpulan data penulis yang digunakan adalah mengelolah data teknik analisis data hasil wawancara dan observasi setelah data dikumpulkan selanjutnya dianalisis data dengan menggunakan tabel frekwensi kemudian di deskripsikan secara kuantitatif.

\section{HASIL DAN PEMBAHASAN}

\section{Koordinasi Antar Lembaga Pemerintah Dalam Pelayanan E-KTP Di Kecamatan Rappocini Kota Makassar.}

Pelaksanaan tugas untuk Penyelenggaraan E-KTP di Kecamatan Rappocini yang menentukan kebijakan baru pemerintah pusat di mana setiap penduduk yang ingin melakukan perekaman dalam pembuatan E-KTP, sebelum perekaman E-KTP masyarakat di wajibkan meminta surat keterangan dari kelurahan, sebab itulah persyaratan bila masyarakat ingin melakukan pembuatan E-KTP. Setelah itu masyarakat bisa membawa langsung dari kecamatan, maka di kecamatan akan dibuatkan database karena pemerintah harus memerlukan NIK masyarakat di mana NIK itu gunanya untuk meminta identitas penduduk Indonesia dan merupakan kunci akses dalam melakukan verifikasi dan validasi data jati diri seseorang guna mendukung pelayanan publik di bidang administrasi kependudukan. NIK ini bersifat unik dan tunggal untuk di berikan kepada setiap penduduk dan berlaku seumur hidup serta selamanya. Nik ini akan di berikan oleh Pemerintah dan diterbitkan oleh Instansi Pelaksanaan di Kabupaten/Kota.

Undang-Undang No. 23 Tahun 2006, khususnya Pasal 13 ayat (3), mengamanatkan bahwa NIK dicantumkan dalam setiap Dokumen Kependudukan dan dijadikan dasar penerbitan Paspor, Surat Izin Mengemudi, Nomor Pokok Wajib Pajak, Polisi Asuransi, Sertifikat Hak Atas Tanah dan penerbitan dokumen identitas lainnya. Hal ini di tujukan unutk mendapatkan kebenaran dan kepastian dokumen kependudukan dan dokumen lainnya bagi setipa penduduk. Program pelayanan dalam Pelaksanaan E-KTP di Kecamatan Rappocini itu, data-data di setiap penduduk yang melakukan perekaman E-KTP akan di verifikasikan jati diri seseorang agar database kependudukan bisa terdaftar pada Pencatatan Sipil.

Sebagaimana yang di kemukakan oleh informan yaitu koordinator Dinas Kependudukan dan Catatan Sipil:

"Pelayanan dalam pembuatan E-KTP di Kecamatan Rappocini sementara proses pelaksanaannya, karena data penduduk yang sudah melakukan perekaman akan di bawa langsung ke Dinas Kependudukan Dan Catatan Sipil. Maka di situ akan di buatkan database, sudah itu langsung di kirim ke Jakarta dengan melalui jaringan satelit". (Wawancara, Fny, 15 April2013)

Namun sampai saat ini pemerintah kurang pengawasan terhadap masyarakat, di mana pemerintah sudah membuat aturan bahwa membuat E-KTP hanya 1 kali saja yang berlaku seumur hidup. Namun di sisi lain banyak masyarakat membuat E-KTP 2 kali, karena pemerintah perlu verifikasi data sebelum membuat KTP Elektronik, agar tidak terjadi kesalahan lagi dalam aturan yang sudah di buat oleh pemerintah.:

"Mengenai pelaksanaan pelayanan E-KTP masih berada pada kategori kurang baik sebab saya melihat peralatan sistem untuk membuat 
E-KTP banyak terkendala seperti perekaman data penduduk, sidik jari, melakukan foto, iris mata. Sebab itu bisa terjadi terlambatnya dalam pembuatan KTP Elektronik. (Wawancara, Us,22 April 2013)

Faktor-faktor Yang Dapat Mempengaruhi Koordinasi Antar Lembaga Pemerintah Dalam Pelayanan E-KTP di Kecamatan Rappocini Kota Makassar.

\section{Faktor Penghambat}

Bahwa E-KTP itu dalah salah satu kebijakan, kemitraan dalam negeri melalui direktorat jenderal kependudukan dan pencatatn sipil jabatan. Berdasarkan Peraturan Presiden No. 26 Tahun 2009 tentang Penerapan Kartu Tanda Penduduk, berdasarkan nomor induk kependudukan secara nasional sebagaimana telah dilakukan perubahan bardasarkan peraturan presiden nomor 35 tahun 2010. Kota Makassar melaksanakan penerapan E-KTP pada tahun 2011 mulai tanggal 15 september 2011. Sampai sekarang bersamaan dengan 197 Kabupaten Kota di seluruh Indonesia sebanyak 500 Kabupaten Kota.

Adapun kendala-kendala yang dihadapi dalam penerapan E-KTP bahwa karena pemerintah Kabupaten Kota hanya melaksanakan dari aspek mobilisasi penduduk untuk melakukan perekaman pada masing-masing kecamatan yaitu 14 Kecamatan di mana sarana prasaranan peralatan E-KTP itu adalah menjadi tanggung jawab Pemerintah pusat untuk diberikan kepada masing-masing Kabupaten Kota. Namun karena kabupaten kota mempunyai potensi yang berbeda dari jumlah penduduk atau wajib E-KTP sementara.

\section{a. Kurangnya Sarana Dan Prasarana}

Pelaksanaan E-KTP pada tahun 2012 di kabupaten/Kota, pada umumnya baru bisa dimulai antara bulan Maret dan April. Ini artinya pelaksanaan tersebut tidak tepat waktu. Sampai saat ini kendala yang tak kunjung terselesaikan di antaranya adalah terlambatnya pengiriman blanko dan alat, banyaknya alat yang rusak, listrik yang tidak tersedia dan jaringan komunikasi data yang belum tersedia.
Hal ini di kemukakan oleh Bapak Kecamatan Rappocini Kota Makassar, bahwa:

"Peralatan yang diberikan kepada masingmasing Kabupaten Kota Makassar sama banyaknya yaitu 2 perangkat komputer untuk setiap Kecamatan, sehingga target penyelesaian perekaman tidak sesuai dengan hitungan-hitungan jumlah wajib E-KTP dengan jumlah waktu yang disedia di tambah masih rendahnya peran aktif masyarakat untuk melakukan perekaman secara antrian sehingga masyarakat cenderung menunda-menundah kesempatan untuk melakukan pere-kaman E-KTP. (Wawancara, IS, 29 April 2013).

Dari Hasil wawancara ini dapat diketahui bahwa kurangnnya peralatan yang terjadi di Kecamatan Rappoicini, sehingga terjadi antrian yang sangat lama itu di sebabkan kurangnya perhatian dari pemerintah, jadi itu biasa di seabkan pelayanan E-KTP untuk masyarakat ini menjadi terlambat.

Demi aspek SDM atau operator pelaksana perekaman tidak melakukan pekerjaan secara cermat dan tepat berdasarkan S.O.P (Standar Operating Prosedur) Pelayanan E-KTP. Ini mengakibatkan terjadinya kesalahan-kesalahan penerbitan E-KTP yang tidak sesuai dengan data yang di miliki, sebenarnya oleh masyarakat karena percetakan dilakukan di pusat (E-KTP). Maka proses perbaikan data E-KTP yang bersangkutan di terima kendala, karena diproritaskan bagi daerah yang akan melakukan E-KTP di tahun 2012.

\section{b. Rendahnya Peran Aktif Masyarakat Dalam Pelayanan E-KTP}

Rendahnya peran aktif masyarakat untuk ikut antrian dalam pelayanan E-KTP menjadi salah satu kendala dalam pendistribusian dan ketiadaan anggaran yang cukup untuk membiayai kegiatan yang menjadi tanggung-jawab pemerintah daerah. Hal ini sesuai penelitian yang ada dilapangan dimana partisipasi masyrakat sangan rendah terhadap E-KTP atau tidak berpartisipasi.

\section{c. Kurang Profesionalnya Operator E- KTP Dalam Melaksanakan Tugas Dan Tanggung Jawab.}


Pemerintah terlalu mengejar target padahal ketersediaan alat serta sumber daya manusianya yang belum memadai seperti kurang profesinalnya operator dalam melaksanakan tugasnya yang mengakibatkan adanya kelambanan dalam proses pembuatan E-KTP serta menyebabkan ketidaknyamanan warga negara. Jika warga negara sebagai konsumen dan pemerintah sebagai penyedia layanan jasa (produsen). Hal ini di perkuat pendapat salah satu tokoh masyarakat di Kelurahan Mappala Kota Makassar yang menyatakan, bahwa :

"Seseorang masyarakat di Kecamatan Rappocini mengaku, dia diminta biaya saat pengambilan E-KTP. Biaya tersebut, dipinta untuk menjamu para operator E-KTP dari mulai makan, minum, rokok dan lain sebagainya."Padahal kemungkinan besar, dari masing-masing desa sudah mengalokasi dana untuk penjamuan para operator tersebut." (Wawancara, Slh, 30 April 2013)

\section{Faktor Pendukung}

Pemerintah merupakan salah satu unsur utama dari sebuah negara kesejahteraan (welfare state) yang bertujuan menciptakan kesejahteraan bagi penduduknya. Untuk itulah maka diperlukan sinergitas antara kepentingan penduduk dengan kepentingan pemerintah. Salah satu bentuk sinergitas antara penduduk dan pemerintah adalah sinergitas dalam kebijakan kependudukan yang dimanifestasikan dalam bentuk peraturan perundangundangan. Adapun faktor pendukung terlaksananya E-KTP yaitu:

\section{a. Adanya Regulasi Tentang Kebijakan Kependudukan}

Adanya regulasi tentang kebijakan kependudukan merupakan dokumen kependudukan yang memuat sistem keamanan/pengendalian baik dari sisi administrasi ataupun teknologi informasi dengan berbasis pada database kependudukan nasional. Penduduk hanya diperbolehkan memiliki 1 (satu) E-KTP yang tercantum Nomor Induk Kepegawaian (NIK). NIK merupakan identitas tunggal setiap penduduk dan berlaku seumur hidup.

Nomor NIK yang ada di E-KTP nantinya akan dijadikan dasar dalam penerbitan Paspor, Surat Izin Mengemudi (SIM), Nomor Pokok Wajib Pajak (NPWP), PolisAsuransi, Sertifikat atas`Hak Tanah dan penerbitan dokumen identitas lainnya (Pasal 13 UU No. 23 Tahun 2006), Proyek E-KTP dilatar belakangi oleh sistem pembuatan KTP konvensional di Indonesia yang memungkinkan seseorang dapat memiliki lebih dari satu KTP.

Menurut Informan Kasi Pemberdayaan Masyarakat di Kecamatan Rappocini menyatakan bahwa :

"Adanya regulasi kebijakan tentang E-KTP Sebagaimana diatur dalam UU No 32 tahun 2004, Tentang Pemerintahan Daerah, Kewenangan daerah mencakup kewenangan dalam seluruh bidang pemerintahan, kecuali kewenangan dalam bidang politik luar negeri, pertahanan keamanan, peradilan, moneter, dan fiskal, agama serta kewenangan bidang lain. Pelayanan publik itu sendiri pada hakekatnya adalah pemberian pelayanan prima kepada masyarakat yang merupakan perwujudan kewajiban aparatur pemerintah sebagai abdi masyarakat. (Wawancara, Az, 29 April 2013)

\section{b. Adanya Anggaran APBN Yang Proporsional}

Secara umum tujuan APBN adalah sebagai pedoman penerimaan dan pengeluaran Negara dalam melaksanakan kegiatan kenegaraan untuk meningkatkan produksi dan kesempatan kerja dalam rangka meningkatkan pertumbuhan ekonomi.

Menurut informan Kasubag Keuangan dan Perlengkapan menyatakan bahwa :

"Biaya paling murah, lebih ekonomis dari pada biometrik yang lain, Bentuk dapat dijaga, tidak berubah karena gurat-gurat sidik jari akan kembali ke bentuk semula walaupun kulit tergores, Unik, tidak ada kemungkinan sama walaupun orang kembar. (Wawancara, Rswdy, 25 April 2013).

\section{E. KESIMPULAN}

Pelaksanaan tugas untuk Penyelenggaraan E-KTP di Kecamatan Rappocini yang menentukan kebijakan baru pemerintah pusat di 
mana setiap penduduk yang ingin melakukan perekaman dalam pembuatan E-KTP, sebelum perekaman E-KTP masyarakat di wajibkan meminta surat keterangan dari kelurahan, sebab itulah persyaratan bila masyarakat ingin melakukan pembuatan E-KTP. Setelah itu masyarakat bisa membawa langsung dari kecamatan, maka di kecamatan akan dibuatkan database karena pemerintah harus memerlukan NIK masyarakat di mana NIK itu gunanya untuk meminta identitas penduduk Indonesia dan merupakan kunci akses dalam melakukan verifikasi dan validasi data jati diri seseorang guna mendukung pelayanan publik di bidang administrasi kependudukan. NIK ini bersifat unik dan tunggal untuk di berikan kepada setiap penduduk dan berlaku seumur hidup serta selamanya. Nik ini akan di berikan oleh Pemerintah dan diterbitkan oleh Instansi Pelaksanaan di Kabupaten/Kota.

Bahwa E-KTP itu dalah salah satu kebijakan, kemitraan dalam negeri melalui direktorat jenderal kependudukan dan pencatatn sipil jabatan. Berdasarkan peraturan presiden No. 26 tahun 2009 tentang penerapan kartu tanda penduduk, berdasarkan nomor induk kependudukan secara nasional sebagaimana telah dilakukan perubahan bardasarkan peraturan presiden nomor 35 tahun 2010.

Kota Makassar melaksanakan penerapan E-KTP pada tahun 2011 mulai tanggal 15 September 2011. Sampai sekarang bersamaan dengan 197 Kabupaten Kota di seluruh Indonesia sebanyak 500 Kabupaten Kota.

Beberapa Faktor yang mempengaruhi Koordinasi Antar Lembaga Pemerintah Dalam Pelayanan E-KTP Di Kecamatan Rappocini Kota Makassar diantaranya, Faktor Penghambat yaitu: Kurangnya sarana dan prasarana, Rendahnya peran aktif masyarakat dalam pelayanan E-KTP, Kurangnya propesional operator E-KTP dalam melaksanakan tugas dan tanggungjawab. Sedangkan Faktor Pendukung yaitu: Adanya regulasi tentang kebijakan kependudukan, Adanya anggaran APBN yang proposional.

\section{DAFTAR PUSTAKA}

Agustino Leo, 2006, Dasar-Dasar Kebijakan Publik, Bandung : Alfabeta
Abidin, Said Zaenal, 2004, Kebijakan Publik, Jakarta : Pancur Siwah,

Basir Barthos, 2001, Manajemen Sumber Daya Manusia: Suatu Pendekatan Makro, Jakarta : PT. Bumi Aksara

Husein Umar, 1997, Riset Sumber Daya Manusia Dalam Organisasi, Jakarta : Gramedia Pustaka Utama

Irawan Soejito, 1981, Hubungan Pemerintah Pusat dan Pemerintah Daerah, Jakarta: Bina Aksara

Irman, 2013, Penerapan NIK Dan KTP Elektronik Di Indonesia, Kemetrian Dalam Negeri R.I, Jakarta.

Manullang, M, 2002. Dasar-Dasar Manajemen, Yogyakarta : Gadjah Mada University Press,

Moenir, A.S. 2002, Manajemen Pelayanan Umum Di Indonesia, Jakarta : Bumi Aksara

Syakhrani, 2009, Implementasi Otonomi Daerah Dalam Perspektif Good Governance, Yogyakarta : Pustaka Pelajar

Sinanmbela LP, 2008, Reformasi Pelayanan Publik Teori, Kebijakan, Dan Implementasi, Jakarta : Bumi Aksara

Soewarno Handayaningrat, 1982, Administrasi Pemerintah Dalam Pembangunan Nasional, Jakarta : PT. Gunung Agung

Salusu, J, 1996, "Pelayanan Berkualitas" Buletin Indikator Volume I No. 2. Pusat Studi Kependudukan UNHAS,

Sianipar, G, 1998, Manajemen Pelayanan Masyarakat, Lembaga Administrasi Negara R.I., Jakarta.

Warta, 2010, Pengaplikasi E-Government, Jakarta : PT. Dian Rakyat, 
Ilham, 2012, Mengenal KTP Electronik Di In- Dokumen Dokumen donesia. (http://www.fahrinilham. blogspot.com/2012/02/mengenalktp-elektronik-di-indonesia.html) Dikunjungi21 Februari 2012

Peraturan Pemerintah Nomor 3 Tahun 2003 Tentang Pengembangan E-Government di Indonesia.

Fradityadi, 2011, Apa dan Mengapa E-KTP. (http://www.ariefradityadi.com/2011 / 11 /index.php? news \& nid=6) Dikunjungi 28 November 2011

Undang-Undang Nomor 23 Tahun 2006 Tentang Administrasi Kependudukan.

Peraturan Pemerintah Nomor 26 Tahun 2009 Tentang Penerapan KTP Berbasis

Sudibyo, 2011, Menyimak KTP Elecktronik Di Nomor Induk Kependudukan. Indonesia. (http://www.deru.blogspot. com/2011/10/menyimak-e-ktp.html) Dikunjungi 04 Oktober 2011 